\title{
PNPRS OFFICERS AND MEMBERS (2020-2021)
}

\section{Officers}

1. Dr. Jove Jim S. Aguas (University of Santo Tomas, Manila) - Executive Governor

2. Dr. Juan Rafael G. Macaranas (De La Salle-College of Saint Benilde, Manila) Chairman

3. Dr. Danilo S. Alterado (Saint Louis University, Baguio) - Vice Chairman

4. Dr. Jeffrey L. Bartilet (Polytechnic University of the Philippines, Manila) - Secretary

5. Mr. Alvin O. Tan (University of Santo Tomas, Manila) - Treasurer

6. Dr. Fleurdeliz R. Altez-Albela (University of Santo Tomas, Manila) - Auditor

7. Dr. Rodrigo D. Abenes (Philippine Normal University-South Luzon, Quezon Province) - Public Relations Officer

8. Ms. Ma. Glovedi Joy L. Bigornia (Hebei Foreign Studies University, Hebei, China) Legal Officer

9. Ms. Basilisa P. Macaranas - Administrative Officer

\section{Members}

10. Ms. Minera Laiza C. Acosta (Polytechnic University of the Philippines, Batangas)

11. Mr. Jomar G. Adaya (Polytechnic University of the Philippines, Manila)

12. Mr. Wilzel A. Adriatico (Ateneo de Manila University, Quezon City)

13. Mr. Joel T. Agacita (Polytechnic University of the Philippines, Manila)

14. Mr. Marlon F. Agoy-Agoy (Polytechnic University of the Philippines, Manila)

15. Mrs. Hermeline B. Aguilar (Polytechnic University of the Philippines, Manila)

16. Dr. Ninotchka Mumtaj B. Albano (De La Salle University, Manila)

17. Mr. Christo Rey S. Albason (Polytechnic University of the Philippines, Manila)

18. Mr. Emmanuel Jeric A. Albela (University of Santo Tomas, Manila)

19. Dr. Albert C. Albina (Negros Oriental State University, Bayawan City)

20. Dr. Jose Arnold L. Alferez, OCDS (Cotabato City State Polytechnic College, Cotabato City)

21. Ms. Ariraya C. Arapia (Polytechnic University of the Philippines, Manila)

22. Ms. Airavie Joy DR. Austria (Polytechnic University of the Philippines, Manila)

23. Mr. Chukwuemeka I. Awugosi (Conversational Society of Philosophy, Africa)

24. Mr. Francis Edward A. Baasis (John Paul II Minor Seminary, Antipolo)

25. Fr. Ziqiang Bai (Chinese University of Hong Kong, Hong Kong)

26. Dr. Efe Baştürk (Recep Tayyip Erdogan University, Rize, Turkey)

27. Mr. Nelson S. Baun (Polytechnic University of the Philippines, Manila)

28. Dr. Hazel T. Biana (De La Salle University, Manila)

29. Ms. Werlie P. Bueno (Polytechnic University of the Philippines, Manila)

30. Dr. Guillermo C. Bungato, Jr. (Polytechnic University of the Philippines, Manila)

31. Mr. Narciso L. Cabanilla (Polytechnic University of the Philippines, Manila)

32. Dr. Mark Joseph T. Calano (Ateneo de Manila University, Quezon City)

33. Dr. Jovito V. Carino (University of Santo Tomas, Manila)

34. Mr. Bernardo N. Caslib, Jr. (University of the Philippines, Manila) 
35. Dr. Jonathan O. Chimakonam (Conversational Society of Philosophy, Africa)

36. Mr. John Peter Chua (Ateneo de Manila University, Quezon City)

37. Ms. Maria Corazon C. Constantino (Polytechnic University of the Philippines, Manila)

38. Mrs. Joan Z. Corañes (Polytechnic University of the Philippines, Manila)

39. Dr. Franz Giuseppe F. Cortez (University of Santo Tomas, Manila)

40. Mr. Artemus G. Cruz (Polytechnic University of the Philippines, Manila)

41. Mr. Jhonley O. Cubacub (Polytechnic University of the Philippines, Manila)

42. Ms. Edelyn H. Dagñalan (Polytechnic University of the Philippines, Manila)

43. Mr. Ian Anthony Davatos (Palawan State University, Philippines)

44. Ms. Jorgina V. David (Polytechnic University of the Philippines, Manila)

45. Ms. Sherrenne R. De Amboy (Polytechnic University of the Philippines, Manila)

46. Ms. Jireh Joy J. De Guzman (Polytechnic University of the Philippines, Manila)

47. Mr. Leonardo R. Dela Cruz (Polytechnic University of the Philippines, Manila)

48. Mr. Glenn V. Dela Cueva (Polytechnic University of the Philippines, Batangas)

49. Dr. Emmanuel C. De Leon (University of Santo Tomas, Manila)

50. Ms. Carmela V. Dellova (Polytechnic University of the Philippines, Manila)

51. Mr. Ferdinand D. Delos Reyes (University of Asia and the Pacific, Pasig)

52. Mr. Florante E. Delos Santos (University of Makati, Makati)

53. Dr. Feorillo Petronillo A. Demeterio III (De La Salle University, Manila)

54. Mr. Angel M. Duque (Polytechnic University of the Philippines, Manila)

55. Dr. Mario R. Echano (Ateneo de Manila University, Quezon City)

56. Mr. Peter Paul E. Elicor (Ateneo de Davao University, Davao City)

57. Fr. Francis Paul S. Escaño (Rogationist Academy Davao, Davao City)

58. Dr. Alma S. Espartinez (Dela Salle-College of Saint Benilde, Manila)

59. Ms. Pia Merla H. Esperida (Polytechnic University of the Philippines, Manila)

60. Ms. Ana Maria L. Espiritu (Polytechnic University of the Philippines, Manila)

61. Fr. Jose Conrado A. Estafia (Immaculate Heart of Mary Seminary, Bohol)

62. Dr. Edwin Etieyibo (University of Witwatersrand, South Africa)

63. Dr. Hyginus Chibuike Ezebuilo (Nnamdi Azikiwe University, Nigeria)

64. Ms. Rimando E. Felicia (Polytechnic University of the Philippines, Manila)

65. Mr. Jimmy M. Fernando (Polytechnic University of the Philippines, Manila)

66. Mr. Diosdado P. Franco (Polytechnic University of the Philippines, Manila)

67. Dr. Crescencia C. Gabijan (Focolare Movement, Tagaytay City)

68. Fr. Julius M. Galarosa (Mater Dei College, Silay City, Negros Occidental)

69. Mr. Fritz C. Galero (Polytechnic University of the Philippines, Manila)

70. Mr. Carlos A. Garcia (Polytechnic University of the Philippines, Manila)

71. Fr. Patrick Gnanapragasam (University of Madras, India)

72. Dr. Blessing G. Glova (Polytechnic University of the Philippines, Manila)

73. Mr. Ivan Efreaim A. Gozum (Angeles University Foundation, Angeles City, Pampanga)

74. Dr. Eden M. Gripaldo (Quezon City)

75. Mr. Joshua Cedric A. Gundayao (University of the Philippines-Diliman, Quezon City)

76. Mr. Rolando T. Herrero (Polytechnic University of the Philippines, Manila) 
77. Dr. Husein Inusah (University of Cape Coast, Central Region, Ghana)

78. Mr. Jayno P. Jabonillo (University of Santo Tomas, Manila)

79. Dr. Jeremiah Joven B. Joaquin (De La Salle University, Manila)

80. Mr. Joseph Martin M. Jose (De La Salle University, Manila)

81. Ms. Jenalyn Y. Lai (Polytechnic University of the Philippines, Manila)

82. Ms. Emelinda C. Layos (Polytechnic University of the Philippines, Manila)

83. Fr. Jose Adriand Emmanuel L. Layug (Immaculate Conception Major Seminary, Bulacan)

84. Ms. Lilian M. Litonjua (Polytechnic University of the Philippines, Manila)

85. Ms. Jalaine Joyce V. Malabanan (Polytechnic University of the Philippines, Manila)

86. Ms. Mayluck A. Malaga (Polytechnic University of the Philippines, Manila)

87. Mr. Rolan J. Malvar (Polytechnic University of the Philippines, Manila)

88. Ms. Lorraine Charmayne S. Manansala (Polytechnic University of the Philippines, Manila)

89. Mr. Peter Emmanuel A. Mara (University of Santo Tomas, Manila)

90. Mr. Edmon D. Marquez (Philippine Normal University-South Luzon, Quezon Province)

91. Mr. Jean Paul G. Martinez (Polytechnic University of the Philippines, Manila)

92. Ms. Estelita E. Medina (Polytechnic University of the Philippines, Manila)

93. Ms. Mary Jane G. Mendoza (Polytechnic University of the Philippines, Manila)

94. Ms. Jennifer D.C. Munsayac (Polytechnic University of the Philippines, Manila)

95. Br. Rambang Ngawan (Dominican Province of the Philippines, Manila)

96. Dr. Nguyen Thi Minh Ngoc (Institute of Sociology, Hanoi, Vietnam)

97. Dr. Charles C. Nweke (Nnamdi Azikiwe University, Awka, Anambra State, Nigeria)

98. Ms. Gerlie C. Ogatis (Polytechnic University of the Philippines, Manila)

99. Mr. Stephen C. Okeke (Nnamdi Azikiwe University, Awka, Nigeria)

100.Dr. Nnaemeka Justin Onyeukaziri (Providence University, Shalu-Taichung City,

Taiwan

101.Ms. Florinda H. Oquindo (Polytechnic University of the Philippines, Manila)

102.Dr. Ian Raymond B. Pacquing (University of Santo Tomas, Manila)

103.Dr. Roland Theuas DS. Pada (University of Santo Tomas, Manila)

104.Dr. Glenn G. Pajares (University of San Jose-Recoletos, Cebu City)

105.Dr. Gabriel Pal'a (University of Presov in Presov, Slovakia)

106.Ms. Rebecca E. Palma (Polytechnic University of the Philippines, Manila)

107.Dr. Engelbert C. Pasag (Panpacific University, Urdaneta City)

108.Dr. Marc Oliver D. Pasco (Ateneo de Manila University, Quezon City)

109.Mr. Mc Donald Domingo Pascual (Polytechnic University of the Philippines, Manila)

110.Dr. Martina Pavlíková (Constantine the Philosopher University in Nitra, Slovakia)

111.Ms. Jane S. Pulma (Polytechnic University of the Philippines, Manila)

112.Dr. Joezenon A. Purog (Eastern Visayas State University, Tacloban City)

113.Dr. Christine Carmela R. Ramos (Mapua University, Manila)

114.Mr. Francis Kenneth P. Raterta (De La Salle University, Manila)

115.Mr. Anton Heinrich L. Rennesland (University of Santo Tomas, Manila)

116.Dr. Raniel S.M. Reyes (University of Santo Tomas, Manila)

117.Mr. Blaise D. Ringor (University of Santo Tomas, Manila) 
118.Ms. Glenda D. Salorsano (Polytechnic University of the Philippines, Manila) 119.Dr. Hilda F. San Gabriel (Polytechnic University of the Philippines, Manila) 120.Mr. Marvin Jhan Santos (University of the Philippines-Diliman, Quezon City) 121.Dr. Beverly A. Sarza (De La Salle University, Manila) 122.Dr. Marek Slomka (The John Paul II Catholic University of Lublin, Poland) 123.Mr. Bonifacio C. Solsoloy (University of Southern Mindanao, Cotabato) 124.Dr. Peter Šturák (University of Presov in Presov, Slovakia) 125.Ms. Agnes M. Sunga (Polytechnic University of the Philippines, Manila) 126.Ms. Christine Abigail L. Tan (Nanyang Technological University, Singapore) 127.Dr. Corazon T. Toralba (University of Asia and the Pacific, Pasig) 128.Dr. William Tullius (American Public University, USA) 129.Mr. Antonius C. Umali (Polytechnic University of the Philippines, Manila) 130.Dr. Miroslav Vacura (University of Economics, Prague, Czech Republic) 131.Dr. Michal Valco (University of Presov in Presov, Slovakia) 132.Dr. Katarína Valčová (Comenius University of Bratislava, Slovakia) 133. Ms. Marienel N. Velasco (Polytechnic University of the Philippines, Batangas) 134.Mr. Paulo Benedicto C. Villar (Polytechnic University of the Philippines, Manila) 135.Ms. Ann-Lyn O. Vinuya (Polytechnic University of the Philippines, Manila) 136.Mr. Joseph Reylan B. Viray (Polytechnic University of the Philippines, Manila) 